University of Nebraska - Lincoln

DigitalCommons@University of Nebraska - Lincoln

Publications of the US Geological Survey

US Geological Survey

4-2004

Prairie Wetlands are Important for Carbon Storage

Jay Hestbeck

Northern Prairie Wildlife Research Center

Follow this and additional works at: https://digitalcommons.unl.edu/usgspubs

Part of the Earth Sciences Commons

Hestbeck, Jay, "Prairie Wetlands are Important for Carbon Storage" (2004). Publications of the US

Geological Survey. 32.

https://digitalcommons.unl.edu/usgspubs/32

This Article is brought to you for free and open access by the US Geological Survey at DigitalCommons@University of Nebraska - Lincoln. It has been accepted for inclusion in Publications of the US Geological Survey by an authorized administrator of DigitalCommons@University of Nebraska - Lincoln. 


\title{
PRAIRIE WETLANDS ARE IMPORTANT FOR CARBON STORAGE
}

\author{
Northern Prairie Wildlife Research Center \\ Jamestown, North Dakota
}

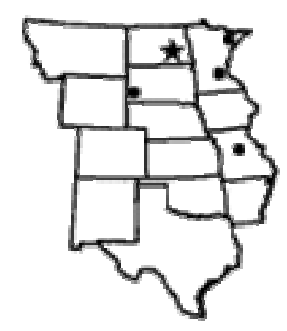

USGS's Northern Prairie Wildlife Research Center and USDA's Agricultural Research Service collaborated to study the potential of prairie pothole region wetlands to sequester carbon emitted into the atmosphere from the burning of fossil fuels. Results suggest that wetlands traditionally functioned as sinks for atmospheric carbon, but cultivation, the current principal land use, has shifted their function to be sources of atmospheric carbon. Data suggest that equal or greater amounts of atmospheric carbon can be stored in wetlands through restoration programs when compared with cropland, even though the acreage of wetlands is much smaller. These restored wetlands will also provide improved habitat for wildlife in the prairie pothole region.

\section{Why Should We Care?}

Evidence for global warming is increasing and there is growing public concern over the management of global greenhouse gases. The Kyoto Protocol represents an international effort by many industrialized nations to reduce greenhouse emissions. Although the United States has not ratified the Kyoto Protocol, we share concerns over global climate change and are committed to seeking appropriate solutions.

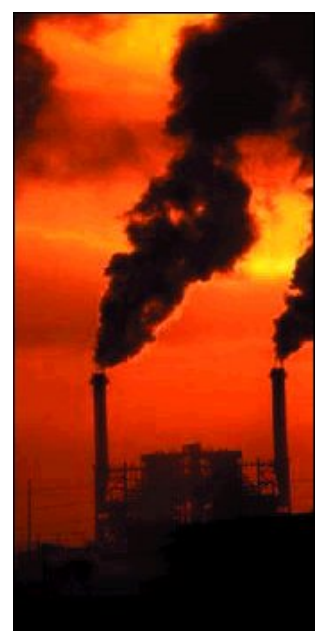

\section{What Can We Do?}

The finding that prairie wetlands are important for carbon storage presents a new opportunity for industry to partner with private landowners to store carbon emitted into the atmosphere. A recent Joyce Foundation grant was used to create a market for trading greenhouse gas emissions (see www.chicagoclimatex.com) that initially targeted a 7-state area in the Midwest but will expand to international markets by 2004. Carbon storage is also being implemented directly between industry and private land owners. Entergy, a leading utility company, has committed to purchasing 30,000 tons of carbon stored by zero-tillage farmers over the next 10 years. Further, storage of carbon in agricultural soil and marketing of carbon credits has been the subject of much debate by various state legislatures and during the drafting of the federal farm bill.

Wetlands provide additional opportunities for carbon trading and storage.

\section{What Next?}

Our initial work on carbon storage in prairie wetlands focused on the two most common wetland types and land-use. Information on total greenhouse gas fluxes is needed for other wetland types and different agricultural land-uses to identify cost-effective methods that maximize storage of atmospheric carbon in wetlands.
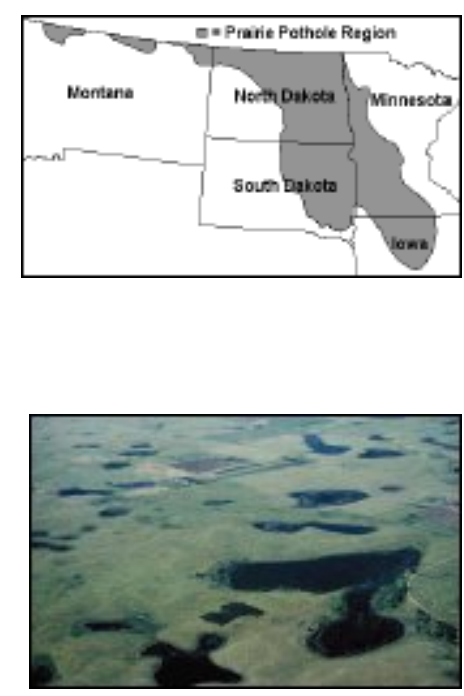

\section{FOR MORE INFORMATION:}

Jay B. Hestbeck, Ph.D.

Center Director

Northern Prairie Wildlife Research Center

8711 37th St. SE

Jamestown, ND 58401-7317

701-253-5515

jay_hestbeck@usgs.gov 